\title{
Youthquake: Neoliberalism and the Ethnicization of Generation
}

\author{
Andrew Dawson \\ University of Melbourne, Melbourne, Australia \\ Email: dawsona@unimelb.edu.au
}

How to cite this paper: Dawson, A (2018). Youthquake: Neoliberalism and the Ethnicization of Generation. Advances in Anthropology, 8, 10-17.

https://doi.org/10.4236/aa.2018.81002

Received: November 19, 2017

Accepted: December 25, 2017

Published: December 28, 2017

Copyright (C) 2018 by author and Scientific Research Publishing Inc. This work is licensed under the Creative Commons Attribution International License (CC BY 4.0).

http://creativecommons.org/licenses/by/4.0/

\begin{abstract}
Through an ethnographic case-study of a former coalmining town in England this article explores relationships between neoliberal restructuring and changes in inter-generational relations. I argue that neoliberalism has produced significant inter-generational structural schisms that, in turn have formed the basis of significant inter-generational cultural schisms. Furthermore, I argue that in several ways these bear the qualities of ethnic divisions.
\end{abstract}

\section{Keywords}

Neoliberalism, Inter-Generational, Youth, Older People, Class, Ethnicity

\section{Introduction: From Class to Ethnicity to Generation}

In an insightful analysis of the existential predicament of the British working-class, Edwards, Evans \& Smith (2012: p. 7) state, "it seemed, by the end of the first decade of the twenty-first century, that the only way to be a viable person in Britain was to be middle class or ethnic". Their comments relate specifically to the "Third Way" politics of the Labour government that came to power in 1997. Traditionally the party of the working class, a category that is still predominantly white, Labour abandoned class politics in favour of neoliberal meritocracy, and, effectively white privilege in favour of multiculturalism. This situation produced significant senses of disenfranchisement amongst the white working class especially (Evans, 2012). Disenfranchisement has persisted and significantly tainted politics through to the present day.

Perhaps the most recent salient example of working-class disenfranchisement was the drift through the 2010s of voters from the Labour Party to other parties such as the United Kingdom Independence Party (UKIP). UKIP's raison d'être was withdrawal of the UK from the European Union. Central appeals of this 
agenda and UKIP in general were, undoubtedly control of unfettered immigration and, at least for some, reassertion of English values (contra those of the immigrant) in British civic life.

Having said this, by the late 2010s it was becoming clear that another schism, which appeared to transcend both class and ethnicity, was beginning to mark life in Britain most - that between old and young. Respected columnist Owen Jones (2017: p. 1) describes poetically, "two Britains living in almost parallel universes". He is not wrong. Probably the most potent manifestation of the generational divide is what came to be known as-in the Oxford English Dictionary's word of the year-the "Youthquake": the remarkable result in the 2017 General Election in which Labour won $61.5 \%$ of the vote in the under-40 age group and the ruling Conservatives won a 50-point lead amongst the over-70s (Jones, 2017: p. 2). The significance of the schism is all the greater because of the ideological divide between the two parties, which was perhaps larger in the election than at any point in almost three decades. In short, whilst the Conservatives held firm to neoliberal orthodoxy, Labour fought the election on a Socialist agenda more radical than, perhaps any leading leftist political party in Europe, with only the possible exception of the Socialist government in Portugal.

The generational split in ideological preferences is hardly surprising. By way of illustration I offer two startling examples of a deeper structural divide that it reflects. The household income of the typical pensioner has risen in recent years by $10 \%$ per annum. In contrast, household income in general in the UK has fallen by $1 \%$ per annum, a figure lowered only by Greece amongst OECD countries (Tily, 2017). Likewise, whilst home-ownership amongst pensioners jumped from $63 \%$ in 1997 to $77 \%$ in 2016 , under-35s have experienced a fall in home-ownership over the same period of 54\% - 34\% (Willetts, 2017).

It is tempting to posit the worsening position of younger people in Britain to the Global Financial Crisis (GFC) of 2008. Likewise, it is tempting to view the worsening position of younger people in Britain as uniform across the UK. Conversely, as I go on to demonstrate, the situation has deeper roots, specifically in the advent of neoliberalism. Likewise, as I also go on to demonstrate, it is a situation experienced unevenly. Most obviously, it is impacted significantly by class. However, "classes" are in and of themselves remarkably heterogeneous groups of people differentiated by a range of factors (Rhodes, 2012), especially the constellations of particular kinds of employment in particular places, and how they have been affected differently by neoliberal change. To this end, in this article, which is a counterpoint to other work that considers intra-generational affinities between people of different ethnic groups (Dawson, 2017), I ground my analysis of the inter-generational structural and cultural schisms generated by neoliberal change in Britain within a case study (1).

\section{Ashington: From Butskellism to Neoliberalism}

The bulk of the post-World War II era in the UK was characterised by what came to be known as the "Butskellite" consensus. Butskellism's economic core 
was Keynesianism and centralised economic management, especially through the lever of large-scale nationalised industry. Its core social dimension was state welfarism.1979, however marked a watershed, with the advent of what came to be known loosely as neoliberalism. Neoliberalism's effects were, undoubtedly felt hardest in the country's predominantly working-class industrial heartlands, places such as Ashington.

Located in the northeast England county of Northumbria, Ashington town comprises a population of roughly 22,000. It grew from little more than a cluster of hamlets around the coalmining industry, whose inception lay in the Industrial Revolution. Indeed, for most of its existence Ashington was, by and large a single-industry town, especially following nationalisation in 1946, and the massive development of mining that presaged. Furthermore, whether true or not, Ashington was celebrated locally as being "the biggest mining village in the World".

Above all, neoliberalism heralded abandonment of centralised economic management and the embracing of market economics. This involved large-scale privatisation, the end of protectionism for domestic industries, and the opening-up of industry to global competition for goods and services. The principal outcome was de-industrialisation. In Ashington the decline in mining that the area had experienced since the mid-1960s became terminal, with the area's last deep coalmine closing in 1994.

A further key tenet of neoliberalism was especially pertinent in light of the wide-scale unemployment that de-industrialism brought. Besides the advent of free market economics, neoliberalism brought curtailment of welfarism, with significant cutbacks in the rates and in the spread of provisioning. Linked to this neoliberalism also brought a gradual shift from the conceptualisation of welfare as a resource to be earned, through active job-seeking and the like, rather than an entitlement.

The kinds of structural schisms-in income, housing and the like-that have been studied nationally (see above) appear, on the basis of anecdotal evidence at least, to have been replicated locally, in Ashington. However, this is not my concern here. Rather, in the manner of interpretive anthropology, I explore below the meanings given to those structural schisms and the cultural schisms between generations that they are seen widely to produce. Furthermore, and fitting for a scholar who has focussed on the issue of old age (Dawson, 2010), I consider in particular how older people view younger people. I illuminate three broad stereotypes: youth as "lesser", "non-" or "Other" persons. Furthermore, and centrally I argue that, akin to processes that take place in the construction of ethnicity, these processes may be seen as indicative of what might be regarded as a kind of "ethnicization of generation".

\section{What Do Older Persons Think of Younger Persons?}

\subsection{Lesser Persons}

Scholarship on coal-mining communities in Britain has highlighted cultures of 
"respectability" (see, for example, Williamson, 1982) through which, in the absence of significant economic differences people evaluate one another in terms of valorised lifestyles. Central amongst such valorised lifestyles are the capacities to independently provide for one's family and to own or, at least keep a home. Ideally, these should be facilitated through gainful employment in "real jobs". In the case of men, the traditional breadwinners in mining communities, real jobs are invariably conceptualised as entailing manual labour.

In each case the ability for younger people to live up to a valorised lifestyle has been effected by neoliberal change. The ability to provide has been diminished not only through post-industrial unemployment, but also through the kinds of "poor work" (Shildrick et al., 2012) that have come to replace mining employment, and that are a typical outcome of neoliberal restructuring. Invariably, such work, which is mostly in the service, retail, leisure, housing and light industrial sectors is poorly paid and, often precarious. Its most pernicious form entails the "zero-hours contract". This may involve no obligation on the part of the employer to provide either a consistent timetable of work, or a minimum number of working hours. Conversely, workers are often required to provide their labour at the employer's behest.

Not surprisingly, in the contexts of employment change and welfare cut-backs increases in poverty are reported amongst working age people, both those who do not work and some who do. Indicative of this and the "Big Society" approach to tackling poverty promulgated by Conservative governments in the 2010s, in which responsibility for care of the poor is devolved from the state to society, Ashington has, like other areas (Caplan, 2016), witnessed the proliferation of charitable "food banks".

Additionally, of course, an inevitable outcome of poverty is increasing inability not only to care for one's family, but especially to provide a home. Moreover, this situation is exacerbated by neoliberal restructuring of housing. Local authorities are compelled to sell properties at below-market rates to existing tenants, but prohibited from re-investing in new housing stock. Inevitably, levels of homelessness locally are reported to be increasing, especially amongst younger people. Conversely, their local elders have become property owners in unprecedented numbers.

Clearly, given the above the ability for younger people to live up to local ideas of valorised lifestyle has been diminished significantly by neoliberal change. Even those who are able to find work, and even "good work", are not immune. For, most of the few available jobs do not correspond to historic local ideals of "real jobs". In particular, for men work in the service, retail and leisure sectors is commonly regarded as feminine work. As many older people rudely, but tellingly remark, “young people today....they're nothing but pufters" (2).

\subsection{Non-Persons}

De-industrialization involves more than loss of the material means of attaining 
locally valorised lifestyles. As stated, Ashington emerged from the Industrial Revolution around a single-industry, mining. The profound effects of this experience on other places like Ashington is perfectly encapsulated in the title of Dennis, Henriques and Slaughter's seminal ethnography of an English coalmining town-"Coal is Our Life" (Dennis et al., 1956). In essence, in such single-industry contexts local culture and ontologies are often, as Edwards (2012) implies viewed locally as industrially determined. In this context closure of industry is also often seen as entailing loss of community (Dawson, 1998) and, even senses of being (see, for example, Thorleifsson, 2016).

Having said this, just like Fordism (Muehlebach \& Shoshan, 2012), industry often leaves traces in the psychologies, cultures and socialities of those who experienced it, despite its passing. It is in this way that older people persist, and not at all ironically, in referring to Ashington as the biggest coal-mining town in the World. As we discuss elsewhere, practices engendered in mining, especially surrounding the social organisation of production continue to frame other practices far removed from the coal-face, such as how people care for others and how they treat death (Dawson \& Goodwin-Hawkins, 2017). Deprived of the experience of the mining life, the material referent for such practices, younger people are frequently conceptualised by older people as being fundamentally culturally different to themselves. More than this, since mining is often conceptualised as core to what it is to "be" an Ashingtonian, younger people are sometimes conceptualised as being what might be described as non-persons. As one older man inchoately, but tellingly put it to me, "young people today.... what are they? Puff (gesturing the blowing of dust). Nothing".

\section{3. "Other" Persons}

Notwithstanding the above, the most common negative remark made by older people about younger people is their description as "Chavs". The term emerges from a broader discourse of what is commonly described as "povertyism", in which the New Right (3) and the middle-classes stigmatize lower classes. Stereotypically Chavs exhibit an inability to adapt to new neoliberal economic realities (Edwards et al., 2012), and a range of negative behaviours: typically, indolence, sexual promiscuity, welfare dependency, anti-social tendencies and criminality. Hence, one assumed origin of the word- "Council House And Violent" (Nayak, 2009) (4).

Deployment of the term Chav by older people in Ashington to describe the town's younger residents is a most curious turn of events. For it refers to the very working-class within which most Ashingtonians, regardless of age, can be classified. In short, local older people use and deploy middle-class stereotypes internally and inter-generationally in order to "Other" their "own" (see also, Dawson, 2017).

\section{Conclusion and Discussion: Ethnicizing Generation}

Writing against older approaches in which the ethnic group is defined by its 
possession of certain objective criteria, such as a shared religion and common ancestry, Eriksen (1993) defines ethnicity as an "emic category of self-ascription". His work builds upon the canonical work of Frederik Barth, for whom ethnicity is a processual category constructed at the boundaries between groups and in which each group forms its view of itself in juxtaposition to the other and its view of the other in juxtaposition to itself (Barth, 1969). Radically subjectivist and relational approaches of this variety found, perhaps no more daring an exposition than in the work of Abner Cohen, who challenged us to think of even stockbrokers as an ethnic group (Cohen, 1974).

Since the publication of Cohen's provocative work it has become commonplace to conceptualise some occupational and class groups as possessing the characteristics of ethnicity. Famously, for example, Okely (1983) challenged the myth of the Indian origin of Britain's Traveller people, arguing that they had formed initially as a class fraction who worked in occupations at the fringes of the economy. Over time they developed the attributes of an ethnic group, even in the classic objective senses of a shared culture and common ancestry. In recent years this kind of work has been developed further in a genre of literature that explores the "ethnicization of class" in concrete relation to neoliberalism and multiculturalism in Britain, and in which the working-class are depicted as viewing themselves merely as one ethnic group amongst others struggling for recognition (Sveinson, 2009).

In this article, and through a case-study of a former coalmining town, I have described how neoliberal restructuring through the post-Butskellite era in Britain has produced significant inter-generational structural and cultural schisms. Their most visible manifestation may have been the "Youthquake" General Election result of 2017. I began by characterising inter-generational schism as "transcending" class and ethnicity. But, historic anthropological work on the mutability of class and ethnicity may cause pause for thought. I have described the meanings attributed by older people in Ashington to the inter-generational structural and cultural schisms they experience. In essence, many such older people have come to view younger people as "lesser persons", as "non-persons" (in the sense that they have not had access to the kinds of working experiences central to what it means to "be" in this context), and as "Others". Such views, especially that of "Others", are typical within processes of ethnicity construction. However, I take this line of analysis further, and into new territory, arguing that the inter-generational relations which neoliberalism has produced in Britain may be seen as akin to ethnic division. Furthermore, as I have demonstrated, the intergenerational division is overlaid by a significant ideological division between neoliberalism and the more radically Socialist agenda of the Labour Party in its current guise. Thus, in conclusion one might feasibly speculate that generational matters will come to trump matters of class and ethnicity as key drivers in British politics in the near future. 


\section{Notes}

1) My research, carried out over many years since the mid-1980s to the present, is based on interrogation of secondary sources and ethnographic fieldwork, especially amongst older residents of an English post-industrial town. Ethnography, as we know, is an approach that deploys a range of qualitative research techniques, especially unstructured interviews and participant observation. As someone of considerable familiarity with the context both as a researcher and native, my research has relied predominantly on participant observation, in the contexts of the everyday lives of my informants.

2) A pejorative term used to describe homosexuals.

3) A term used to describe a broad cluster of political groups that are ideologically to the right of mainstream conservatism.

4) Council housing is the local government form of housing provided predominantly for the poor.

\section{References}

Barth, F. (1969). Ethnic Groups and Boundaries: The Social Organisation of Cultural Difference. Bergen: Universitetsforlaget.

Caplan, P. (2016). Big Society or Broken Society? Food Banks in the UK. Anthropology Today, 32, 5-9. https://doi.org/10.1111/1467-8322.12223

Cohen, A. (1974). Urban Ethnicity. London: Psychology Press.

Dawson, A. (1998). The Dislocation of Identity: Contestations of "Home Community" in Northern England. In N. J. Rapport, \& A. Dawson (Eds.), Migrants of Identity: Perceptions of Home in a World of Movement (pp. 207-224). Oxford and New York: Berg.

Dawson, A. (2010). Ageing and Change in Pit Villages of North East England. Melbourne: University of Melbourne Custom Books.

Dawson, A. (2017). Hating Immigration and Loving Immigrants: Nationalism, Electoral Politics and the Post-Industrial White Working-Class in Britain. Anthropological Notebooks, 23, Not Assigned.

Dawson, A., \& Goodwin-Hawkins, B. (2017). Post-Fordist Death: A Comparative Ethnographic Analysis of Milling and Mining in Northern England. Death Studies. https://doi.org/10.1080/07481187.2017.1396397

Dennis, N., Henriques, F., \& Slaughter, C. (1956). Coal Is Our Life: Analysis of a Yorkshire Mining Community. London: Eyre and Spottiswoode.

Edwards, J. (2012). Ancestors, Class, and Contingency. Focaal-Journal of Global and Historical Anthropology, 62, 70-80. https://doi.org/10.3167/fcl.2012.620106

Edwards, J., Evans, G., \& Smith, K. (2012). Introduction: The Middle-Classification of Britain. Focaal-Journal of Global and Historical Anthropology, 62, 3-16.

Eriksen, T. H. (1993). Ethnicity and Nationalism: Anthropological Perspectives. London: Pluto Press.

Evans, G. (2012). "The Aboriginal People of England": The Culture of Class Politics in Contemporary Britain. Focaal-Journal of Global and Historical Anthropology, 62, 17-29. https://doi.org/10.3167/fcl.2012.620102

Jones, O. (2017). The Question Labour Must Answer: Why Isn't It Further Ahead in the Polls? The Guardian. Retrieved 1 December 2017. 
https://www.theguardian.com/commentisfree/2017/nov/29/question-labour-must-ans wer-further-ahead-polls

Muehlebach, A., \& Shoshan, N. (2012). Post-Fordist Affect: Introduction. Anthropological Quarterly, 85, 317-343. https://doi.org/10.1353/anq.2012.0030

Nayak, A. (2009). Beyond the Pale: Chavs, Youth and Social Class. In P. K. Sveinson (Ed.), Who Cares about the White Working Class (pp. 28-35)? London: Runnymeade.

Okely, J. (1983). The Traveller Gypsies. Cambridge: Cambridge University Press. https://doi.org/10.1017/CBO9780511621789

Rhodes, J. (2012). The "Trouble" with the "White Working Class": Whiteness, Class and "Groupism". Identities: Global Studies in Culture and Power, 19, 485-492. https://doi.org/10.1080/1070289X.2012.710548

Shildrick, T., MacDonald, R., Webster, C., \& Garthwaite, K. (2012). Poverty and Insecurity: Life in Low-Pay, No-Pay Britain. Bristol: Policy Press. https://doi.org/10.1332/policypress/9781847429117.001.0001

Sveinson, K. P. (2009). Who Cares about the White Working Class? London: Runnymeade.

Thorleifsson, C. (2016). From Coal to Ukip: The Struggle over Identity in Post-Industrial Doncaster. History and Anthropology, 27, 555-568. https://doi.org/10.1080/02757206.2016.1219354

Tily, G. (2017). UK $103^{\text {rd }}$ Out of 112 in Global Ranking for Real Wage Growth Since the Crisis. Economics. Retrieved 8 August 2017.

http://touchstoneblog.org.uk/2017/02/uk-103rd-112-global-ranking-real-wage-growthsince-crisis/

Willetts, D. (2017). How Unequal Is the UK-And Should We Care? London: Resolution Foundation.

Williamson, B. (1982). Class, Culture and Community: A Biographical Study of Social Change in Mining. London: Routledge and Kegan Paul. 